\title{
Pengaruh Pembiayaan Murābahah terhadap Peningkatan Usaha Anggota Koperasi Mitra Manindo Kantor Kas Siabu
}

\author{
Tri Surya ${ }^{1}$, Muhammad Isa ${ }^{2}$, Aliman Syahuri Zein ${ }^{3}$ \\ ${ }_{1,2,3}^{1}$ Institut Agama Islam Negeri Padangsidimpuan \\ 1,2,3JL. H.T. Rizal Nurdin, Km. 4,5 Sihitang Kota Padangsidimpuan - Sumatera Utara \\ alimansyahurizein@gmail.com
}

\begin{abstract}
Abstrak
Latar belakang masalah dalam penelitian ini adalah adanya perbedaan pendapatan antara nasabah yang menggunakan pembiayaan murābahah di Koperasi Mitra Manindo Kantor kas Siabu. Tujuan penelitian adalah mengetahui pengaruh pembiayaan murābahah terhadap peningkatan usaha anggota Koperasi Mitra Manindo Kantor kas Siabu. Penelitian ini merupakan penelitian kuantitatif. Sumber data yang digunakan adalah data primer. Teknik pengumpulan data yang digunakan adalah angket, dengan jumlah sampel 86 nasabah. Alat analisis yang digunakan adalah uji validitas dan reliabilitas, uji normalitas, Statistik deskriptif, analisis regresi sederhana, uji hipotesis (uji t), uji koefisien determinasi $\mathrm{R}^{2}$. Dengan menggunakan program SPSS Versi 22.o. Nilai r-square sebesar 0,194 berarti 19.4\% variabel Pembiayaan murabahah mampu menerangkan variabel peningkatan usaha di koperasi Mitra Manindo kantor kas Siabu, sedangkan sisanya sebesar 80.6\% dipengaruhi oleh variabel lain yang tidak dibahas dalam model ini. Berdasarkan Uji t diketahui bahwa pembiayaan murābahah memiliki pengaruh terhadap peningkatan usaha anggota Koperasi Mitra Manindo Kantor kas Siabu.
\end{abstract}

\section{Kata Kunci: Koperasi, Pembiayaan, Pendapatan}

\begin{abstract}
The background of the problem in this study is the difference in income between customers who use murābahah financing at the Koperasi Mitra Manindo Siabu cash office. The research objective was to determine the effect of murābahah financing on increasing the business of members of the Koperasi Mitra Manindo Siabu cash office. This research used quantitative method. The data source used is primary data. The data collection technique used was a questionnaire, with a sample size of 86 customers. The analytical tool used is the validity and reliability test, normality test, descriptive statistics, simple regression analysis, hypothesis testing (t-test), test the coefficient of determination R2. By using the SPSS Version 22.o program. The r-square value of 0.194 means that 19.4\% of the Murabahah financing variable can explain the business improvement variable in the Mitra Manindo cooperative, Siabu cash office, while the remaining $80.6 \%$ is influenced by other variables not discussed in this model. Based on the t-test, it is known that murābahah financing affects increasing the business of members of the Koperasi Mitra Manindo Siabu cash office.
\end{abstract}

Keywords: Cooperative, Financing, Income 
124|Pengaruh Pembiayaan Murabahah Terhadap Peningkatan Usaha Anggota Koperasi Mitra Manindo Kantor Kas $\mathrm{S}$ i a b u

\section{PENDAHULUAN}

Salah satu koperasi syariah yang berdiri di Mandailing Natal adalah koperasi Mitra Manindo. Koperasi Mitra Manindo didirikan para tokoh Mandailing Natal dengan mengadaptasi sistem Grameen Bank di Bangladesh dengan memberikan pinjaman tanpa agunan. Untuk memperlancar upaya tersebut maka diperlukan pendampingan guna mengarahkan agar proses replikasi tidak mengabaikan prinsip-prinsip dasar Grameen Bank (Buku Panduan Koperasi Mitra Manindo, 2012). Koperasi Mitra Manindo berdiri berdasarkan Surat Keputusan Menteri Negara Koperasi dan Usaha kecil dan Menengah nomor 843/BH/MENEG.I/V/2009 tanggal 14 Mei 2009 tentang Pengesahan Akta Pendirian Koperasi Mitra Manindo (Manan, 2012).

Tujuan pendirian koperasi Mitra Manindo adalah untuk meningkatkan kualitaS usaha ekonomi anggota pada khususnya dan masyarakat pada umumnya. Koperasi Mitra Manindo menyediakan produk pembiayaan murābahah yang diberikan kepada anggota koperasi berorientasi pada upaya peningkatan kesejahteraan anggota. Koperasi ini sudah mulai tumbuh dan berkembang secara swadaya dan dikelola secara profesional (Manan, 2012). Koperasi Mitra Manindo memiliki kantor kas di Siabu, Kabupaten Mandailing Natal dan dibuka pada tanggal 1 Mei 2012, berdirinya koperasi Mitara Manindo kantor kas Siabu didasari oleh besarnya minat masyarakat terhadap koperasi berbasis syariah. Dimana jika dilihat dari pekembangan jumlah anggota Koperasi Mitra Manindo Kantor Kas Siabu mengalami fluktuasi sebagaimana dalam tabel berikut:

Berdasarkan tabel di atas dapat dilihat bahwa kenaikan jumlah anggota Koperasi Mitra Manindo Kantor Kas Siabu pada tahun 2012 berjumlah 179 anggota, dan mengalami peningkatan sebanyak 357 maka pada tahun 2013 berjumlah sebanyak 536 anggota, hal ini dikatakan sangat signifikan. Kemudian pada tahun 2014 juga mengalami peningkatan sebanyak 217 dan menjadi jumlah keseluruhan pada tahun tersebut sebanyak 753 anggota, dan pada tahun 2015 Koperasi Mitra Manindo Kantor Kas Siabu mengalami penurunan menjadi 628 anggota.

Pembiayaan murābahah yang sediakan oleh pihak koperasi Mitra Manindo kantor kas Siabu bertujuan untuk menambah modal usaha para anggota yang menggunakan pembiayaan. Penambahan modal usaha diharapkan mampu meningkatkan perekonomian anggota. Peningkatan perekonomian tersebut dapat dilihat dari tingkat pendapatan dan kesejahteraan anggota. Pendapatan usaha tersebut tergantung besar kecilnya modal yang digunakan, jika modal yang dikeluarkan oleh anggota besar maka pendapatan yang diterima oleh anggota akan bertambah, begitu juga dengan sebaliknya jika modal yang dikeluarkan oleh anggota kecil maka pendapatan yang diterima anggota akan sedikit. Untuk itu diperlukan adanya pemberian 
pembiayaan dalam menjalankan suatu usaha guna meningkatkan pendapatan usaha anggotanya.

Produk pembiayaan murābahah Koperasi Mitra Manindo diberikan kepada masyarakat yang memiliki usaha rumahan (home industry) sebagai penambahan modal usaha, Koperasi Mitra Manindo kantor kas Siabu memberikan pembiayaan mulai dari Rp. 100.000,- sampai dengan Rp. 5.000.000,- cara pembayarannya dapat dilakukan harian, mingguan, atau bulanan sesuai dengan kesepakatan antara koperasi Mitra Manindo kantor kas Siabu dengan anggota.

Hasil wawancara peneliti dengan salah satu anggota yang melakukan pembiayaan pada koperasi Mitra Manindo kantor kas Siabu yang bernama Ummi, beliau memperoleh pembiayaan murābahah sebesar Rp. 1.500.00o,- sedangkan modal awal Ibu Ummi tersebut berjumlah Rp. 2.750.000,- dimana pendapatan awalnya sebesar Rp. 80.000,-/hari setelah memperoleh pembiayaan, pendapatannya meningkat hanya sebesar Rp. 90.000,-/hari. Sedangkan hasil wawancara dengan Ibu Riadoh yang memiliki usaha rumahan (warung) menerima pembiayaan murābahah sebesar Rp. 1.00o.ooo, Sedangkan modal awal Ibu Riadoh berjumlah sebesar Rp. 2.000.ooo,- Sebelum menerima pembiayaan pendapatan Ibu Riadoh rata-rata sebesar Rp. 60.000,-/hari, dan setelah menerima pembiayaan rata-rata pendapatan Ibu Riadoh masih menetap berjumlah sebesar Rp. 60.00o,-/hari.

Berdasarkan pernyataan di atas dapat dikatakan bahwa usaha Ibu Ummi memiliki peningkatan pendapatan setelah menerima pembiayaan murābahah sebagai tambahan modal usaha. Namun Ibu Riadoh yang menerima pembiayaan sebesar Rp. 1.ooo.ooo.- tidak memiliki pengaruh terhadap pembiayaan murabahah yang diberikan oleh koperasi Mitra Manindo kantor kas Siabu.

\section{KAJIAN TEORITIS}

Kegiatan usaha koperasi adalah kegiatan yang dilakukan untuk menghimpun dana dan menyalurkannya melalui pemberian pembiayaan koperasi dari dan untuk anggota koperasi yang bersangkutan (Dinas Koperasi Dan Usaha Mikro Kecil dan Menengah Provinsi Jawa Tengah, n.d.). Untuk mencapai maksud dan tujuan sebagaimana dimaksud dalam pasal 4 pada buku Panduan Koperasi Mitra Manindo, maka koperasi menyelenggarakan usaha bidang sosial dan bidang bisnis, kegiatan usaha bidang sosial koperasi adalah sebagai berikut (Buku Panduan Koperasi Mitra Manindo, 2012):

1) Penggalangan sumber dana sosial antara lain zakat, infak, sedekah, wakaf, serta dana sosial lainnya. 
2) Penyaluran dana sosial yang diutamakan untuk mengentaskan kemiskinan melalu zakat dan wakaf produktif, pengembangan Sumber Daya Manusia (SDM) serta bidang lainnya sesuai dengan anggaran dasar koperasi.

3) Koperasi dapat membentuk lembaga Amil Zakat Nasional dan bekerja sama dengan lembaga zakat nasional yang sudah ada untuk pengembangan usaha sosial

4) Kegiatan sosial dakwah lainnya yang tidak bertentangan dengan anggaran dasar sosial.

Koperasi berasal dari kata cooperation yang berarti kerja sama. Sedangkan menurut istilah, yang dimaksud dengan koperasi adalah suatu perkumpulan yang dibentuk oleh para anggota peserta yang berfungsi untuk memenuhi kebutuhan para anggotanya dengan harga yang relatif rendah dan bertujuan memajukan tingkat hidup bersama (Dinas Koperasi Dan Usaha Mikro Kecil dan Menengah Provinsi Jawa Tengah, n.d.). Koperasi adalah lembaga usaha yang dinilai cocok untuk memberdayakan rakyat kecil. Nilai-nilai koperasi juga mulia seperti keadilan, kebersamaan, kekeluargaan, dan kesejehateraan bersama.

Syariah adalah kata dari bahasa Arab yang berarti jalan yang harus ditempuh atau garis yang mestinya dilalui. Secara terminologi syariah adalah peraturan-peraturan dan hukum yang telah digariskan oleh Allah Swt. atau telah digariskan pokok-pokoknya dan dibebankan kepada kaum muslimin supaya mematuhinya (Karim, 2013). Selain itu koperasi syariah sering disebut suatu perserikatan dengan tujuan berusaha bersama yang terdiri atas mereka yang lemah dan terus diusahakan selalu dengan semangat tidak memikirkan diri sendiri sedemikian rupa koperasi merupakan lembaga keuangan yang usaha pokoknya memberikan pembiayaan dan jasa-jasa yang tidak menggunakan bunga tetapi menggunakan sistem bagi hasil (Chaniago, 1984). Sedangkan menurut peneliti koperasi syariah adalah perkumpulan atau kerja sama yang mempunyai peraturan dan hukum-hukum sesuai dengan syariat Islam untuk menjalankan perekonomian yang dilandasi dengan aturan syariah untuk bekerja sama secara kekeluargaan menjalankan usaha untuk mempertinggi jasmaniah para anggotanya.

Pembiayaan merupakan salah satu tugas koperasi, yaitu pemberian fasilitas penyediaan dana untuk memenuhi kebutuhan pihak-pihak yang merupakan defisit unit. Menurut sifat penggunaanya, pembiayaan dapat dibagi menjadi dua hal yaitu:

1) Pembiayaan produktif, yaitu pembiayaan yang ditunjukkan untuk memenuhi kebutuhan produksi dalam arti luas, yaitu untuk peningkatan usaha, baik usaha produksi, perdagangan maupun investasi.

2) Pembiayaan konsumtif, yaitu pembiayaan yang digunakan untuk memenuhi kebutuhan konsumsi, yang akan habis digunakan untuk pemenuhan kebutuhan. 
Menurut keperluannya, pembiayaan produktif dapat dibagi menjadi dua hal berikut (Antonio, 2001); Pembiayaan modal kerja, yaitu pembiayaan untuk memenuhi kebutuhan; Pembiayaan investasi, yaitu untuk memenuhi kebutuhan barang-barang modal serta fasilitas-fasilitas yang berkaitan.

\section{Unsur Pembiayaan}

Pembiayaan pada dasarnya memiliki beberapa unsur yang diberikan atas kepercayaan sesuai dengan penjelasan sebagai berikut (Veithzal \& Veithzal, 2008):

1) Adanya dua pihak, yaitu pemberian pembiayaan (shāhibul māl) dan penerima dana (mudhārib).

2) Adanya kepercayaan shahibul mal kepada mudhārib yang didasarkan atas prestasi dan potensi mudhārib

3) Adanya persetujuan berupa kesepakatan pihak shāhibul māl dengan pihak lainnya yang berjanji membayar dari mudhārib kepada shāhibul māl.

4) Adanya penyerahan barang, jasa atau uang dari shāhibul māl kepada mudhārib

5) Adanya unsur waktu (time element)

6) Adanya unsur risiko diantara kedua pelaku.

Hubungan pemberi pembiayaan dengan penerima pembiayaan merupakan kerja sama yang menguntungkan atas dasar persetujuan diantara kedua belah pihak, dan pembiayaan terjadi diikuti dengan adanya unsur waktu, baik dilihat dari shāhibul māl maupun dari mudhārib.

\section{Fungsi Pembiayaan}

Pembiayaan dapat membantu masyarakat dalam memenuhi kebutuhan dalam meningkatkan usaha dan juga berfungsi dalam meningkatkan perekonomian antara lain sebagai berikut (Ismail, 2011):

1) Pembiayaan dapat meningkatkan arus tukar menukar barang dan jasa, maka pembiayaan dapat memperlancar pertukaran barang dan jasa.

2) Pembiayaan merupakan alat yang digunakan untuk mempertemukan pihak kelebihan dana dan kekurangan dana, sehingga akan efektif dana tersebut dimanfaatkan oleh pihak yang membutuhkan dana dengan cara yang tepat dan bermanfaat.

3) Adanya pembiayaan yang diberikan, dapat meningkatkan taraf ekonomi yang lebih baik. 


\section{Manfaat Pembiayaan}

Menurut Adiwarman A. Karim Pembiayaan tentunya harus memiliki manfaat bagi masyarakat luas. Adapun dari sisi pembiayaan teradapat beberapa manfaat yang diperoleh antara lain (Karim, 2013).

1) Mengurangi tingkat pengangguran. Pembiayaan yang diberikan untuk perusahaan dapat menyebabkan adanya tambahan tenaga kerja karena adanya peningkatan volume produksi, tentu akan menambah jumlah tenaga kerja.

2) Melibatkan masyarakat yang memiliki profesi tertentu misalnya akuntan, notaris, appraisal independent, asuransi. Pihak ini diperlukan oleh bank untuk mendukung kelancaran pembiayaan.

3) Penyimpan dana akan mendapat imbalan berupa bagi hasil lebih tinggi dari bank apabila bank dapat meningkatkan keuntungan atas pembiayaan yang disalurkan.

4) Memberikan rasa aman bagi masyarakat yang menggunkan pelayanan jasa perbankan atau non bank.

\section{Jenis-jenis Pembiayaan}

Dalam menjelaskan jenis-jenis pembiayaan, dapat dilihat dari segi tujuan, jangka waktu yang menerima dan memberi pembiayaan serta lokasi tempat usaha.

1) Jenis pembiayaan dilihat dari tujuan

a) Pembiayaan konsumtif

Menurut Adiwarman A Karim, Pembiayaan konsumtif adalah jenis pembiayaan yang diberikan untuk tujuan di luar usaha dan umumnya bersifat perorangan. ${ }^{1}$ Sedangkan menurut Veithzal Rivai dan Andria Permata Veithzal Pembiayaan konsumtif bertujuan untuk memperoleh barang-barang atau kebutuhan-kebutuhan lainnya guna memenuhi keputusan dalam konsumsi. Menurut peneliti pembiayaan konsumtif adalah pembiayaan yang diberikan kepada seseorang untuk menutupi kebutuhan sehari-hari diluar kebutuhan usaha.

b) Pembiayaan produktif

Pembiayaan produktif adalah pembiayaan yang ditujukan untuk memenuhi kebutuhan produksi dalam arti luas, yaitu untuk peningkatan usaha baik usaha produksi, perdagangan maupun investasi.

Menurut Veithzal Rivai dan Andria Permata Veithzal pembiayaan produktif ialah:

(1) Meyakinkan si penerima pembiayaan untuk mewujudkan targetnya. 
(2) Memperlancar jalannya proses produksi, mulai dari saat pengumpulan bahan mentah, pengolahan, dan sampai kepada proses penjualan barang-barang yang sudah jadi.

2) Jenis pembiayaan dilihat dari jangka waktu

a) Pembiayaan jangka pendek ialah pembiayaan yang berjangka waktu maksimum 1 tahun.

b) Pembiayaan jangka waktu menengah ialah pembiayaan yang berjangka waktu dari 1 tahun sampai 3 tahun.

c) Pembiayaan jangka panjang ialah pembiayaan yang berjangka waktu lebih dari 3 tahun.

3) Jenis pembiayaan dilihat menurut lembaga

a) Pembiayaan untuk badan usaha pemerintah/daerah, yaitu pembiayaan yang diberikan kepada perusahaan/badan usaha yang dimiliki pemerintah.

b) Pembiayaan untuk badan usaha swasta, yaitu pembiayaan yang diberikan kepada perusahaan/badan usaha swasta.

c) Pembiayaan perorangan, yaitu pembiayaan yang diberikan bukan perusahaan, tetapi kepada perorangan (Veithzal \& Veithzal, 2008).

\section{Kualitas Pembiayaan}

Pembiayaan menurut kualitas pada hakikatnya didasarkan atas risiko kemungkinan terhadap kondisi dan kepatuhan nasabah dalam memenuhi kewajiban untuk membayar bagi hasil, serta melunasi pembiayaannya. Berdasarkan kualitas pembiayaan terbagi atas (Veithzal \& Veithzal, 2008):

1) Pembiayaan lancar (pass), pembiayaan yang digolongkan lancar apabila pembiayaan angsuran pokok dan margin tepat waktu.

2) Dalam perhatian khusus (spesial mention), pembiayaan digolongkan pembiayaan dalam perhatian khusus apabila memenuhi kriteria:

a. Terdapat tunggakan angsuran pokok dan margin yang belum melampaui sembilan puluh hari.

b. Jarang terjadi pelanggaran terhadap kontrak yang diperjanjikan.

c. Didukung oleh pinjaman baru.

3) Kurang lancar (substandar), pembiayaan yang digolongkan ke dalam pembiayaan kurang lancar apabila memenuhi kriteria sebagai berikut:

a. Terdapat tunggakan angsuran pokok dan margin.

b. Terjadi pelanggaran terhadap kontrak yang diperjanjikan lebih dari sembilan puluh hari. 
130| Pengaruh Pembiayaan Murabahah Terhadap Peningkatan Usaha Anggota Koperasi Mitra Manindo Kantor Kas $\mathrm{S}$ i a b u

c. Terdapat indikasi masalah keuangan yang dihadapi debitur.

4) Macet (loss), pembiayaan yang digolongkan ke dalam pembiayaan macet apabila memenuhi kriteria:

a. Terdapat tunggakan angsuran pokok dan bagi hasil.

b. Kerugian operasional ditutupi dengan pinjaman baru.

\section{Pembiayaan Murābahah}

\section{Pengertian Murābahah}

Akad jual beli murābahah dalam fikih dikenal sebagai jual beli yang keuntungan ditentukan di awal. Jual beli ini dilakukan secara kredit, jual beli ini dibolehkan karena mengandung kemaslahatan bagi masyarakat (Ridwan, 2005). Menurut Kamus Lengkap Ekonomi Islam yang ditulis oleh Dwi Suwiknyo murābahah itu merupakan penjualan barang dengan margin keuntungan yang disepakati dan penjual memberitahukan biaya perolehan dan barang yang dijual tersebut (Suwikyo, 2009).

Jadi singkatnya, murābahah adalah akad jual beli barang dengan menyatakan harga perolehan dan keuntungan (margin) yang disepakati oleh penjual dan pembeli. Karena dalam definisinya disebut adanya"keuntungan yang disepakati” karakter murābahah adalah si penjual harus memberitahu pembeli tentang harga pembelian barang dan menyatakan jumlah keuntungan yang ditambahkan pada biaya tersebut (Karim, 2013). Oleh karena itu, murābahah tidak dengan sendirinya mengandung konsep pembayaran tertunda (delayed payment), seperti yang secara umum yang dipahami oleh sebagian orang yang mengetahui murābahah hanya dalam hubungannya dengan transaksi pembiayaan di perbankan syariah, tetapi tidak memahami fiqh Islam.

Menurut peneliti murābahah adalah salah satu bentuk jual beli yang mewajibkan penjual memberikan informasi kepada pembeli tentang biaya-biaya yang harus dikeluarkan untuk mendapatkan salah satu barang yang ingin dibayar sipembeli penjual harus memberi tahu pembeli tentang harga pembelian barang dan menyatakan jumlah keuntungan yang ditambahkan.

\section{Landasan Hukum Murābahah}

Landasan hukum syariah murābahah berdasarkan ketentuan DSN (Dewan Syariah Nasional) Nomor 04/DSN-MUI/IV/2000 dalam surah Al-Baqarah ayat 275 dimana Allah telah menghalalkan jual beli dan mengharamkan riba (Departemen Agama RI, 1999). Dalam hal jual beli, ada hal-hal yang menyebabkan dihalalkannya jual beli, dan dalam masalah riba, ada faktor-faktor yang menyebabkan haramnya riba. Penyebab dihalalkannya jual beli, karena selama pihak pembeli bisa memanfaatkan apa yang dibeli dalam artian hakiki. Siapa saja yang membeli gandum misalnya, maka sekali-kali ia tidak membeli kecuali untuk dimakan, JISFIM: Journal of Islamic Social Finance Management, Volume 1, No 1 Tahun 2020 http://jurnal.iain-padangsidimpuan.ac.id/index.php/JISFIM 
disemaikan bijinya, atau untuk dijual lagi (sebagai perdagangan). Di samping itu harga yang ditetapkan berimbang dengan barang yang dijual secara rela antara penjual dengan pembeli dan dengan pilihan antara keduanya (Ridwan, 2005).

Begitu halnya dengan pembiayaan murābahah, selama pihak yang diberi pembiayaan memanfaatkan dana yang diberikan oleh pemberi pembiayaan sesuai dengan perjanjian pada akad pembiayaan maka pembiayaan murābahah tersebut adalah halal.

\section{Rukun dan Syarat Murābahah}

Rukun dari akad murābahah yang harus dipenuhi dalam transaksi yaitu sebagai berikut (Suhendi, 2011):

1. Pelaku akad, yaitu ba’i (penjual) adalah pihak yang memiliki barang untuk dijual, dan musytari (pembeli) adalah pihak yang memerlukan dan akan membeli barang.

2. Objek akad, yaitu mabi' (barang dagangan) dan tsaman (harga); dan

3. Shighah, yaitu ijab dan kabul akan tetapi, validitas transaksi seperti ini tergantung pada beberapa syarat yang benar-benar harus diperhatikan agar transaksi tersebut diterima secara syariah. Menurut Suhendi beberapa syarat pokok murābahah sebagai berikut:

a) Murābahah merupakan salah satu bentuk jual beli ketika penjual secara eksplisit menyatakan biaya perolehan barang yang akan dijualnya dan menjual kepada orang lain dengan menambahkan tingkat keuntungan yang diinginkan.

b) Tingkat keuntungan dalam murābahah dapat ditentukan berdasarkan kesepakatan bersama dalam bentuk lumpsum atau persentase tertentu dari biaya.

c) Semua biaya yang dikeluarkan penjual dalam rangka memperoleh barang, seperti biaya pengiriman, pajak, dan sebagainya dimasukkan ke dalam biaya perolehan untuk menentukan harga agregat dan margin keuntungan didasarkan pada harga agregat ini. Akan tetapi, pengeluaran yang timbul karena usaha, seperti gaji pegawai, sewa tempat usaha, dan sebagainya tidak dapat dimasukkan ke dalam harga untuk suatu transaksi. Margin keuntungan yang diminta itulah yang mengcover pengeluaranpengeluaran tersebut.

d) Murābahah dikatakan sah hanya ketika biaya-biaya perolehan barang dapat ditentukan secara pasti. Jika biaya-biaya tidak dapat dipastikan, barang/komoditas tersebut tidak dapat dijual dengan prinsip murābahah.

\section{METODE PENELITIAN}

Penelitian ini dilakukan di Koperasi Mitra Manindo Kantor Kas Siabu Kelurahan Siabu, Kecamatan Siabu, Kabupaten Mandailing Natal. Waktu penelitian ini mulai dari bulan April sampai dengan Juni 2016. Penelitian yang akan dilaksanakan adalah penelitian kuantitatif. Penelitian kuantitatif adalah penelitian yang menggunakan data kuantitatif/ data yang JISFIM: Journal of Islamic Social Finance Management, Volume 1, No 1 Tahun 2020 http://jurnal.iain-padangsidimpuan.ac.id/index.php/JISFIM 
132 | Pengaruh Pembiayaan Murabahah Terhadap Peningkatan Usaha Anggota Koperasi Mitra Manindo Kantor Kas $\mathrm{S}$ i a b u

berbentuk angka atau data yang diangkakan. Adapun jenis penelitian ini adalah penelitian korelasional yang bertujuan menetukan hubungan atau pengaruh antara dua variabel atau lebih dalam suatu penelitian (Arikunto, 2006).

Populasi adalah kelompok besar individu yang mempunyai karakteristik yang sama, atau populasi adalah wilayah generasi yang terdiri dari objek atau subjek yang mempunyai kuantitas dan karakteristik tertentu yang ditetapkan oleh peneliti untuk dipelajari, dan kemudian ditarik suatu kesimpulan (Ruslan, 2004). Adapun yang menjadi populasi penelitian ini yaitu anggota koperasi Mitra Manindo kantor kas Siabu yang berjumlah 628 anggota. Sampel adalah bagian kecil dari anggota populasi yang diambil berdasarkan teknik tertentu sehingga dapat mewakili populasinya (Tanjung \& Devi, 2013), atau sampel merupakan bagian atau sejumlah cuplikan tertentu yang diambil dari suatu populasi dan diteliti secara rinci (Muhamad, 2008). Diketahui jumlah populasi anggota koperasi Mitra Manindo kantor kas Siabu sebanyak 628 anggota. Pengukuran tingkat signifikasi yang digunakan 10\% atau (0.1). Dalam pengambilan sampel ini Suharsimi Arikunto menjelaskan dalam isi bukunya, untuk pengukuran taraf signifikansi pengetesan artinya kesediaan yang berwujud besarnya probabilitas jika hasil penelitian terhadap sampel akan diterapkan pada populasi. Besarnya taraf signifikansi ini pada umumnya sudah diterapkan lebih dahulu misalnya 0.15, 0.05, dan o.01. Jadi penelitian ini mengambil taraf signifikansi sebesar 10\% (0.1) untuk pengukuran sampel penelitian yang dilakukan (Arikunto, 2006).

Berdasarkan perhitungan di atas bahwa sampel sebanyak 86,26 dibulatkan menjadi 86 responden dari 628 populasi. Sampel inilah yang diambil pada anggota koperasi Mitra Manindo kantor kas Siabu. Sedangkan teknik pengambilan sampel peneliti menggunakan simple random sampling yaitu mengambil sampel secara acak tanpa memperhatikan kelas, usia, strata dan jenis kelamin. Kuesioner yang dipakai disini adalah model tertutup karena jawaban telah disediakan dan pengukurannya menggunakan skala likert, skala likert adalah lima pilihan jawaban dari sangat tidak setuju sampai dengan sangat setuju yang merupakan sikap atau persepsi seseorang atas suatu kejadian atau pernyataan yang diberikan dalam instrumen/kuesioner (Suryani \& Hendriyadi, 2015).

Dalam penggunaannya, peneliti lebih terdahulu menetapkan secara spesifik variabelvariabel penelitian lengkap dengan indikator-indikator ini kemudian dijadikan sebagai titik tolak untuk menyusun instrumen penelitian dalam bentuk pertanyaan dan pernyataan. Jawaban dari setiap pertanyaan atau pernyataan itu mempunyai tingkatan mulai dari sangat positif sampai dengan negatif. Berkaitan dengan pengujian validitas instrumen Arikunto menjelaskan bahwa yang dimaksud dengan validitas adalah suatu ukuran yang menunjukkan tingkat keandalan atau kesahihan suatu alat ukur. Syarat instrumen dikatakan valid maka $r_{\text {hitung }}>\mathrm{r}_{\text {tabel. }}$. Hal tersebut menunjukkan alat ukur yang digunakan untuk mendapatkan data JISFIM: Journal of Islamic Social Finance Management, Volume 1, No 1 Tahun 2020 http://jurnal.iain-padangsidimpuan.ac.id/index.php/JISFIM 
itu valid sehingga valid tersebut dapat digunakan untuk mengukur apa yang seharusnya diukur (Ridwan, 2005).

Pengujian validitas setiap butir yaitu dengan mengkorelasikan skor-skor yang ada pada butir dengan skor total. Skor butir dipandang sebagai nilai X dan skor total dipandang sabagai nilai Y. Dengan diperolehnya indeks validitas setiap butir dapat diketahui dengan pasti butirbutir manakah yang tidak memenuhi syarat ditinjau dari validitasnya.

Reliabilitas merupakan syarat mutlak untuk menentukan pengaruh variabel yang satu terhadap variabel yang satu lagi (Nasution, 2003). Berhubungan instrumen yang diberikan adalah berdasarkan angket maka nilainya yaitu dalam bentuk skor yang diberikan bukan 1 dan o. Dalam penelitian ini untuk uji reliabilitas akan dilakukan dengan program SPSS menggunakan metode Alpha (Cronbach's). pengukuran reliabilitas menggunakan metode Alpha (Cronbach's) akan menghasilkan nilai alpha dalam skala 0-1, yang dikelompokkan dalam lima kelas. Nilai masing-masing kelas dan tingkat reliabilitas mengacu pada Buku Nasution (Nasution, 2003). Analisis data yang digunakan dalam penelitian ini adalah analisis data statistik inferensial dimana peneliti bermaksud melakukan generalisasi atau menaksir populasi berdasarkan data sampel (Suryani \& Hendriyadi, 2015). Pengujian hipotesis tersebut dilakukan dengan menggunakan perhitungan statistik dengan bantuan program komputer yaitu SPSS (Statistical Product and Service Solution) versi 22.o. Uji yang digunakan untuk menganalisis data penelitian ini yaitu: Uji normalitas merupakan uji prasyarat untuk melakukan uji lanjutan yang digunakan dalam perhitungan regresi dalam perhitungan statistik. Untuk melakukan uji normalitas peneliti menggunakan rumus kolmogorov smirnov (Nugroho, 2011). Ketentuan dalam penelitian dapat dikatakan berdistribusi normal apabila nilai absolute lebih besar dari level of signifikan (level 10 \%), sebaliknya data tidak berdistribusi normal apabila nilai absolute lebih kecil dari level of signifikan. Untuk menentukan taraf signifikansi sebagaimana disebutkan oleh Arikunto besar taraf signifikansi pada umumnya sudah diterapkan terlebih dahulu misalnya $0.15,0.05,0.01$ dan sebagainya (Arikunto, 2006).

Fungsi statistik deskriptif adalah untuk mengklasifikasikan suatu data variabel berdasarkan kelompoknya masing-masing dari semula belum teratur dan mudah diinterpretasikan oleh orang yang membutuhkan informasi tentang variabel tersebut. Selain itu statistik deskriptif juga berfungsi menyajikan informasi sedemikian rupa, sehingga data yang dihasilkan dari penelitian dapat dimanfaatkan oleh orang lain yang membutuhkan.

Statistik deskriptif digunakan pada saat deskripsi atau penggambaran sekumpulan data secara visual dapat dilakukan dalam dua bagian yaitu (Muhamad, 2008); Deskripsi dalam bentuk tulisan/teks seperti mencari mean (rata-rata) data, standar deviasi, varian data; Deskripsi dalam bentuk gambar/grafik. 
Uji regresi digunakan untuk meramalkan suatu variabel dependen (Y) berdasarkan satu variabel independen $(\mathrm{X})$ dalam suatu persamaan linear, pengamatan pasangan variabel $\mathrm{X}$ dan $\mathrm{Y}$ digambarkan dengan titik, kemudian titik-titik tersebut dihubungkan sehingga membentuk pola garis. Pola garis tersebut secara matematis dapat didekati dengan suatu garis lurus atau persamaan linear (Trihendradi, 2013). Rumus persamaan garis linear sederhana sebagai berikut:

$$
\mathrm{PU}=a+b P P+e
$$

$$
\begin{array}{ll}
\text { Keterangan: } \\
\text { PU } & \text { : Peningkatan Usaha } \\
\text { PM } & \text { : Pembiayaan Murābahah } \\
\text { a } & \text { : konstanta } \\
\text { b } & \text { : koefisien regresi } \\
\text { e } & \text { : eror. }
\end{array}
$$

Uji t digunakan untuk mengetahui apakah dalam model regresi variabel independen (pembiayaan murābahah) secara parsial berpengaruh signifikan terhadap variabel dependent (peningkatan usaha) (Muhamad, 2008). Untuk mengetahui ada atau tidaknya pengaruh pemberian pembiayaan terhadap peningkatan usaha maka digunakan tingkat signifikan o,1. Jika nilai probabilitas t lebih besar dari o,1 maka ada pengaruh dari pemberian pembiayaan terhadap peningkatan usaha anggota (koefisien regresi tidak signifikan), sedangkan jika nilai probabilitas t lebih kecil dari o,1. Maka terdapat pengaruh pemberian pembiayaan terhadap peningkatan usaha (koefisien regresi signifikan).

Setelah diperoleh $t_{\text {hitung }}$, maka untuk menginterpretasikan hasilnya berlaku ketentuan sebagai berikut; Jika $t_{\text {hitung }}$ lebih besar dari $t_{\text {tabel }}$, maka $\mathrm{H}_{0}$ ditolak dan $\mathrm{H}_{\mathrm{a}}$ diterima, ini berarti tingkat pemberian pembiayaan mempunyai pengaruh yang signifikan terhadap peningkatan usaha anggota; Jika $t_{\text {hitung }}$ lebih kecil dari $t_{\text {tabel }}$, maka $\mathrm{H}_{0}$ diterima dan $\mathrm{H}_{\mathrm{a}}$ ditolak, ini berarti secara parsial tidak ada pengaruh yang signifikan antara pemberian pembiayaan terhadap peningkatan usaha.

\section{Uji Koefisien Determinasi $\mathbf{R}^{2}$}

Analisis determinasi dalam regresi linier sederhana, digunakan untuk mengetahui persentase sumbangan variabel independent $(\mathrm{X})$ yang pada penelitaian ini adalah pemberian pembiayaan terhadap variabel dependent (Y) yang dalam penelitian ini adalah peningkatan usaha. Koefisien ini menunjukkan seberapa besar persentase variasi variabel independent yang digunakan dalam model mampu menjelaskan variasi variabel dependent. $\mathrm{R}^{2}$ sama JISFIM: Journal of Islamic Social Finance Management, Volume 1, No 1 Tahun 2020 http://jurnal.iain-padangsidimpuan.ac.id/index.php/JISFIM 
dengan o, maka tidak ada sedikitpun persentase sumbangan pengaruh yang diberikan variabel independent terhadap variabel dependent, atau variasi variabel independent yang digunakan dalam model tidak menjelaskan sedikitpun variasi variabel dependent. Sebaliknya $\mathrm{R}^{2}$ sama dengan 1, maka persentase sumbangan pengaruh yang diberikan variabel independent terhadap variabel dependent adalah sempurna, atau variasi variabel independent yang digunakan dalam model menjelaskan $100 \%$ variasi variabel dependent.

\section{HASIL DAN PEMBAHASAN}

Hasil Uji Validitas Dan Reabilitas Uji validitas dan reabilitas dilakukan untuk menguji kesahihan dan ketepatan instrument penelitian. Instrumen yang digunakan dalam penelitian ini adalah angket yang disebarkan kepada responden yaitu anggota koperasi Mitra Manindo. Adapun yang menjadi sampel penelitian ini adalah 86 orang. Berdasarkan pengolahan data yang telah dilakukan dengan menggunakan software SPSS versi 22.0 diperoleh hasil untuk variabel pembiayaan murābahah $(\mathrm{X})$ dan Peningkatan Usaha $(\mathrm{Y})$ sudah valid dimana nilai Pearson correlation tiap item > 0.1786. Kemudian, untuk hasil uji reliabilitas semua item pada kedua variabel sudah reliable dimana nilai Cronbach's Alpha untuk variabel pembiayaan murābahah (X) sebesar 0.570 dan untuk variabel Peningkatan Usaha (Y) sebesar 0.697 dimana keduanya > 0.1786. Hasil statistik deskriptif dapat dilihat sebagai berikut ini:

Tabel 1

Hasil Uji Statistik Deskriptif

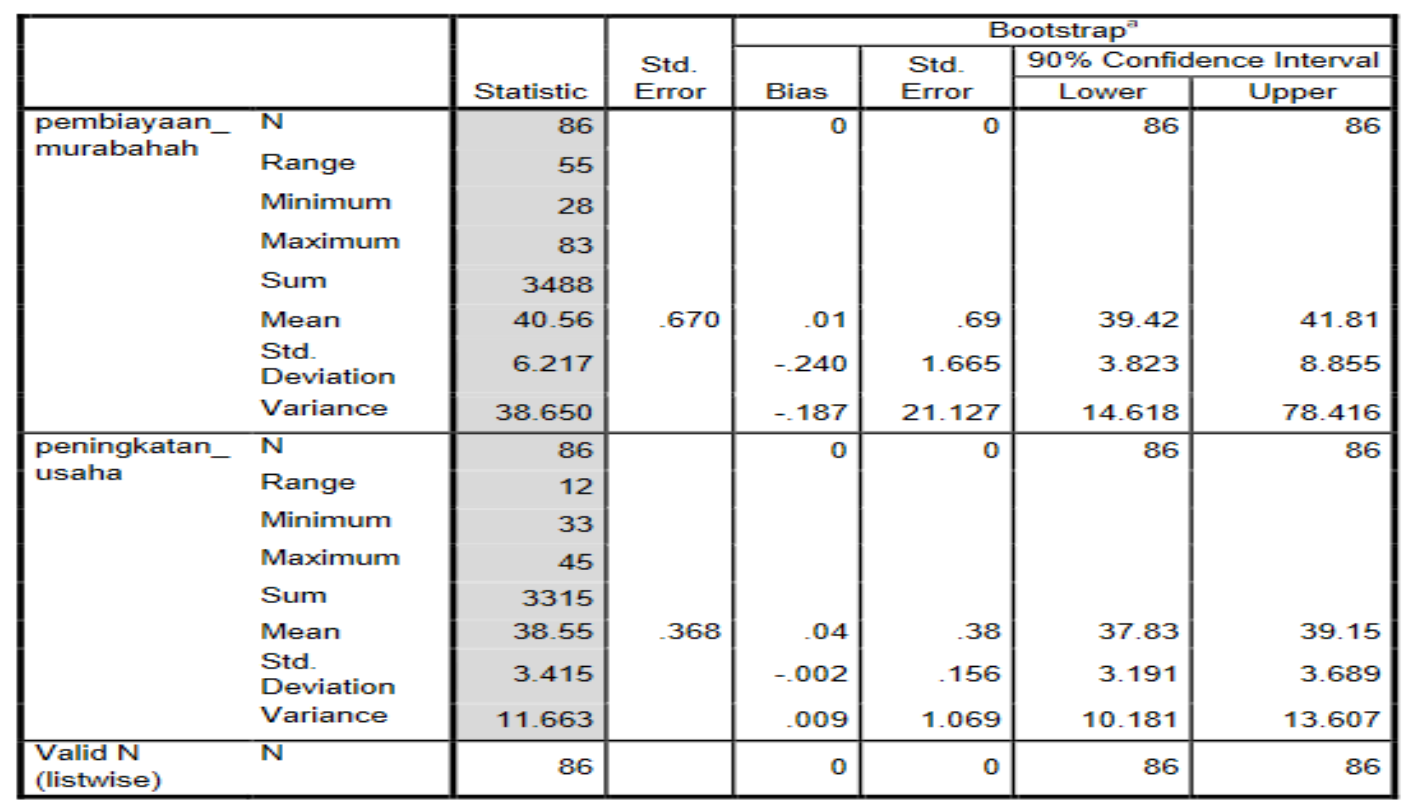

Sumber: Hasil Olah Data (2016)

Dari tabel di atas menunjukkan bahwa jumlah responden $(\mathrm{N})$ ada 86, dari 86 responden ini nilai pembiayaan murabahah yang paling kecil (minimum) adalah 28 dan nilai JISFIM: Journal of Islamic Social Finance Management, Volume 1, No 1 Tahun 2020 http://jurnal.iain-padangsidimpuan.ac.id/index.php/JISFIM 
pembiayaan murabahah terbesar (maximum) adalah 83, Rata-rata nilai dari 86 responden 40.56 dengan Std. Deviation 6.217 sedangkan nilai range merupakan selisih nilai Minimum dan maximum yaitu sebesar 55 dan nilai Sum merupakan penjumlahan dari 86 responden nilai mereka yaitu sebesar 3488 Sedangkan dalam variabel Y Peningkatan Usaha mempunyai nilai paling kecil (minimum) adalah 33 dan nilai peningkatan usaha terbesar (maximum) adalah 45, Rata-rata nilai dari 86 responden 38.55 dengan Std. Deviation 3.415. sedangkan nilai Range merupakan selisih nilai Minimum dan maximum yaitu sebesar 12 dan nilai Sum merupakan penjumlahan dari 86 responden nilai mereka yaitu sebesar 3315 .

Uji Regresi Linier Sederhana Dari pengolahan data yang telah dilakukan dengan menggunakan software SPSS versi 22.0 ternyata komputer mengeluarkan tabel seperti berikut:

\section{Tabel 2}

Hasil Uji Regresi Linier Sederhana

\begin{tabular}{|r|r|r|r|r|r|}
\hline \multirow{2}{*}{ Model } & \multicolumn{2}{|c|}{$\begin{array}{c}\text { Unstandardized } \\
\text { Coefficients }\end{array}$} & \multicolumn{1}{c|}{$\begin{array}{c}\text { Standardized } \\
\text { Coefficients }\end{array}$} & & \\
\cline { 2 - 6 } & $\mathrm{B}$ & Std. Error & Beta & $\mathrm{t}$ & Sig. \\
\hline $1 \quad$ (Constant) & 28.735 & 2.208 & & 13.016 & .000 \\
$\mathrm{x}$ & .242 & .054 & .440 & 4.496 & .000 \\
\hline
\end{tabular}

Sumber: Hasil Olah Data (2016)

Dari tabel di atas dapat dibentuk persamaan regresi linier untuk kedua variabel (pembiayaan murābahah dan peningkatan usaha) seperti berikut:

$$
\mathrm{PU}=28.735+0.242 \mathrm{PM}
$$

Dari persamaan tersebut dapat dijelaskan bahwa antara variabel pembiayaan murābahah (X) dan variabel peningkatan usaha (Y) memiliki hubungan yang searah (+). Artinya apabila pemberian pembiayaan (X) meningkat maka peningkatan usaha (Y) juga akan meningkat. Kemudian setiap peningkatan variabel pembiayaan murābahah(X) sebesar 1\% akan berakibatkan meningkatnya nilai variabel peningkatan usaha (Y) sebesar $0.242 \%$. Sebaliknya setiap pengurangan variabel pembiayaan murābahah (X) sebesar 1\% akan berakibat berkurangnya nilai variabel peningkatan usaha (Y) sebesar $0.242 \%$. 


\section{Tabel 3}

\section{Hasil Uji Hipotesis (Uji t)}

\begin{tabular}{|c|c|c|c|c|c|}
\hline \multirow[b]{2}{*}{ Model } & \multicolumn{2}{|c|}{$\begin{array}{c}\text { Unstandardized } \\
\text { Coefficients }\end{array}$} & \multirow{2}{*}{$\begin{array}{c}\text { Standardized } \\
\text { Coefficients } \\
\text { Beta }\end{array}$} & \multirow[b]{2}{*}{$t$} & \multirow[b]{2}{*}{ Sig. } \\
\hline & $\mathrm{B}$ & Std. Error & & & \\
\hline 1 (Constant) & 28.735 & 2.208 & & 13.016 & .000 \\
\hline$x$ & .242 & .054 & .440 & 4.496 & .000 \\
\hline
\end{tabular}

Sumber: Hasil Olah Data (2016)

Dari tabel di atas terlihat thitung 4.496 dan ttabel 1,66277, karena ttabel < thitung, maka ada pengaruh variabel $\mathrm{X}$ (pembiayaan murabahah) terhadap variabel $\mathrm{Y}$ (peningkatan usaha). Jika dilihat dari kolom signifikansi dapat dibaca nilainya o.ooo yaitu lebih kecil dari o.1. Artinya dapat disimpulkan hubungan antara variabel pembiayaan murābahah dan peningkatan usaha adalah signifikan (pengaruh yang terjadi dapat berlaku untuk populasi).

Tabel 4

Hasil Uji Koefisien Determinasi

\begin{tabular}{|l|r|r|r|r|}
\hline Model & R & R Square & \multicolumn{1}{c|}{$\begin{array}{c}\text { Adjusted R } \\
\text { Square }\end{array}$} & $\begin{array}{l}\text { Std. Error of the } \\
\text { Estimate }\end{array}$ \\
\hline 1 & $.440^{\mathrm{a}}$ & .194 & .184 & 3.084 \\
\hline
\end{tabular}

Sumber: Hasil Olah Data (2016)

Dari tabel di atas terlihat bahwa R square (R2) atau yang sering disebut koefisien determinasi sebesar 0.194 atau 19,4\%. Hal ini menjelaskan bahwa variabel pembiayaan murābahah (X) memberikan pengaruh sebesar 19.4\% terhadap variabel peningkatan usaha (Y), sedangkan sisanya 80.6\% dipengaruhi oleh variabel lain yang tidak diteliti pada penelitian ini.

\section{Pembahasan}

Berdasarkan hasil pengelolaan data yang dilakukan menunjukkan adanya hubungan yang rendah antara variabel pembiayaan murābahah (X) dengan peningkatan usaha (Y). Hal ini ditunjukkan oleh nilai r sebesar 0,440. Padahal berdasarkan literature yang ada (lihat pada bagian landasan teori halaman 32) mengindikasikannya adanya hubungan yang erat antara pembiayaan murābahah terhadap peningkatan usaha. Pada lembaga keuangan seperti koperasi Mitra Manindo kantor kas Siabu kenyataan bahwa pembiayaan murābahah memiliki hubungan yang rendah dengan kepuasan anggota perlu dikaji oleh penelitian yang lebih lanjut. Kemudian dari persamaan regresi yang diperoleh: $\mathrm{PU}=28.735+0.242 \mathrm{PM}$ menunjukkan bahwa adanya hubungan yang positif atau searah. Hal ini mengisyaratkan bahwa setiap usaha meningkatkan variabel pembiayaan murābahah akan meberikan peningkatan terhadap peningkatan usaha. Artinya peningkatan pembiayaan murābahah (X) sebesar 1\% akan 
berakibat meningkatnya nilai variabel peningkatan usaha $(\mathrm{Y})$ sebesar $0,242 \%$. Sebaliknya setiap pengurangan variabel pembiayaan murābahah (X) sebesar $1 \%$ akan berakibat berkurangnya nilai variabel peningkatan usaha $(\mathrm{Y})$ sebesar $0,242 \%$.

Berdasarkan hasil perhitungan uji hipotesis (Uji t) terlihat thitung4.496 dan ttabel 1,66277, karena ttabel < thitung, maka ada pengaruh variabel X (Pembiayaan Murābahah) terhadap variabel Y (Peningkatan Usaha), dan dilihat hasil perhitungan koefisien determinasi diperoleh koefisien determinasi Rsquare (R2) sebesar 0,194 atau 19.4 \% yang menjelaskan bahwa variabel pembiayaan murābahah (X) memberikan pengaruh hanya sebesar $19.4 \%$ terhadap variabel Peningkatan Usaha (Y). Walaupun memberikan pengaruh relatif kecil namun faktor pembiayaan murabahah ini tetap perlu diperhatikan dan ditingkatkan oleh pihak koperasi Mitra Manindo kantor kas Siabu demi meningkatkan kepuasan anggotanya.

\section{KESIMPULAN}

Berdasarkan hasil penelitian tentang Pengaruh pemberian pembiayaan murābahah terhadap peningkatan usaha anggota koperasi Mitra Manindo kantor kas Siabu dapat disimpulkan bahwa uji statistik deskriptif, mendistribusikan bahwa variabel pembiayaan murābahah (X) memiliki 86 responden yang memiliki nilai tertinggi (maximum) 83 dan terendah (minimum) 28, sedangkan rata-ratanya memiliki nilai 40.56 dengan Std. Deviation 6.217. Sementara variabel peningkatan usaha $(Y)$ dengan jumlah responden 86 memiliki nilai tertinggi (maximum) 45 dan nilai terendah (minimum) 33, sedangkan nilai rata-ratanya 38.55 dengan Std. Deviation 3.415. Sedangkan dalam uji hipotesis terlihat $t_{\text {hitung }} 4.496$ dan $t_{\text {tabel }}$ 1.66277, karena $t_{\text {tabel }}<t_{\text {hitung }}$ maka Pemberian pembiayaan murābahah berpengaruh positif terhadap peningkatan usaha anggota koperasi mitra manindo kantor kas Siabu dengan taraf signifikansi o,ooo. Dan pemberian pembiayaan murābahah memberikan sumbangan sebesar 0.194 atau $19.4 \%$.

\section{DAFTAR PUSTAKA}

Antonio, M. S. (2001). Bank Syariah: Dari Teori ke Praktik. Gema Insani.

Arikunto, S. (2006). Prosedur Penelitian Suatu Pendekatan Praktik. Rineka CIpta.

Buku Panduan Koperasi Mitra Manindo. (2012).

Chaniago, A. (1984). Perkoperasian Indonesia. Angkasa.

Departemen Agama RI. (1999). Al-Qur'an dan Terjemahnya. Toha Putra. 
Dinas Koperasi Dan Usaha Mikro Kecil dan Menengah Provinsi Jawa Tengah. (n.d.). Standar Operasional Prosedur. Koperasi Jasa Keuangan Syariah dan Unit Jasa Keuangan Syariah Koperasi-PDF Download Gratis. Retrieved April 28, 2021, from https://docplayer.info/268325-Standar-operasional-prosedur-koperasi-jasakeuangan-syariah-dan-unit-jasa-keuangan-syariah-koperasi.html

Ismail. (2011). Perbankan Syariah. Kencana.

Karim, A. A. (2013). Bank Islam Analisis Fiqih dan Keuangan. PT. Raja Grafindo Persada.

Manan, A. (2012). Hukum Ekonomi Syariah Dalam Perspektif Kewenangan Peradilan Agama. Kencana.

Muhamad. (2008). Metodologi Penelitian Ekonomi Islam. Raja Grafinfo Persada.

Nasution, S. (2003). Metode Research. Bumi Aksara.

Nugroho, Y. A. (2011). Olah Data Dengan SPSS. Skripta Media Creative.

Ridwan, M. (2005). Sistem dan Prosedur Operasional Bank Syari’ah. UII Press.

Ruslan, R. (2004). Metode Penelitian. Raja Grafinfo Persada.

Suhendi, H. (2011). Fiqh Muamalah. Rajawali.

Suryani, \& Hendriyadi. (2015). Metode Riset Kuantitatif Teori dan Aplikasi pada Penelitian Bidang Manajemen dan Ekonomi Islam. Kencana.

Suwikyo. (2009). Kamus Lengkap Ekonomi Islam. Total Media.

Tanjung, H., \& Devi, A. (2013). Metodologi Penelitian Ekonomi Islam. Gramata Publishing.

Trihendradi, C. (2013). Step By Step IBM SPSS. 20. Analisis Data Statistik. CV. Andi Offset.

Veithzal, R., \& Veithzal, A. P. (2008). Islamic Financial Management. RajaGrafindo Persada. 